UDC 81'42'367.3:821.111 «20»

DOI https://doi.org/10.32999/ksu2663-2691/2019-80-6

\title{
PECULIARITIES OF CONTRACTED ELEMENTS IN BRITISH FEMINIST LITERATURE OF THE EARLY 21ST CENTURY
}

\author{
Dzyadyk Yuriy Ivanovych, \\ Assistant Lecturer of the Department of Modern Languages \\ University of Ghana \\ yuridlviv@gmail.com \\ orcid.org/0000-0002-9639-1020
}

The purpose of the research is to analyze the contracted elements in the feminist literature of Great Britain of the postmodern era of the early 21 st century.

The research methodology is based on a comprehensive analysis of the object of study - sentences with contracted elements in British fiction at lexical, grammatical, semantic and communicative-pragmatic levels. The sentences were analyzed in terms of valence, transformational, component and intent analysis. The study of the valence of predicates that can be found in the novels written by women has shown that both verbal and nominative predicates are the basic syntaxemes of the sentence. Transformational method was used to identify the typical features of contracted elements in textual functioning. Component analysis helped to determine the structure of sentences with contracted elements. The method of Intent Analysis was aimed at identifying the intention that motivate communication and is implemented in speech acts and expressed at the language level through contracted elements of the sentence. The scientific novelty of the article is based on the analysis of the contracted components in British women's novels of postmodern era at the text level. A complex approach is applied to the study of sentences with contracted elements; semantic and communicative-pragmatic features are highlighted and their interaction is emphasized. Conclusions. Gender models are well described in the texts, the characters appear in a new system. Gender aspect is visible in an extensive system of different parameters that show the female features in the literary works: an emotionally coloured picture of the world is accepted by readers through women's perception. The plot is based on a romantic love story. Events take place either in foreign countries, or in the castle, on the ranch, or just in some forgotten places. Openness of text on the basis of multicomponent series, syntactic repetition, syncretic constructions are the means that help readers to enter the inner world of heroes. Since each novel is special and new components are introduced to the image of the woman, the specific features of women's prose cannot be fixed models, but vary from novel to novel. The contracted elements used by writers add expressiveness to the description of events.

Key words: postmodernism, valency, intent-analysis, syncretism, grammatical marker.

\section{ОСОБЛИВОСТІ УСІЧЕНИХ ЕЛЕМЕНТІВ У ФЕМІНІСТИЧНІЙ ЛІТЕРАТУРІ ВЕЛИКӦ̈ БРИТАНІЇ ПОЧАТКУ ХХІ СТОЛІТТЯ}

\author{
Дзядик Юрій Іванович, \\ асистент кафедри сучасних мов \\ Університету Гани \\ yuridlviv@gmail.com \\ orcid.org/0000-0002-9639-1020
}

\begin{abstract}
Мета роботи - проаналізувати усічені елементи у феміністичній літературі Великої Британії постмодерністичної доби початку XXI століття. Методологія дослідження спирається на комплексний аналіз об'єкта дослідження - речень з усіченими елементами в англомовному художньому дискурсі на лексико-граматичному, семантичному та комунікативнопрагматичному рівнях. Речення проаналізовано із застосуванням валентного, трансформаційного, компонентного та інтент-аналізу. Дослідження валентності присудка, який наявний у досліджуваному матеріалі, засвідчило, що дієслівний та іменний присудки є основною синтаксемою речення. Трансформаційний метод слугував виявленню характерних ознак усічених елементів в текстовому функціонуванні. Компонентний аналіз сприяв визначенню структури речень 3 усіченими елементами. Метод інтент-аналізу було спрямовано на виявлення інтенцій, які мотивують комунікацію і втілюються в мовленнєвих актах та виражаються на рівні мови через усічені члени речення. Наукова новизна статті полягає у спробі цілісного аналізу усічених компонентів в англомовних жіночих романах на рівні постмодерністичного тексту. Застосовано комплексний підхід до розгляду речень з усіченими членами, встановлено семантичні та комунікативно-прагматичні характеристики та визначено їх взаємодію. Висновки. У текстах чітко простежуються гендерні моделі, персонажі постають у новій системі координат. Гендерний аспект становить собою розгалужену систему різних параметрів, які увиразнюють ознаки жіночності у творах: емоційно забарвлена картина світу, яка постає перед читачами у жіночому сприйнятті. В основі сюжету - романтична історія кохання. Події відбуваються або в заморських країнах, або в замку, на ранчо, чи просто в якихось забутих усіма місцях. Відкритість тексту на основі багатокомпонентних рядів, синкретичні конструкції, синтаксичні повтори - засоби, що допомагають читачеві зануритися у внутрішній світ героїв. Оскільки кожен роман $є$ особливим і до зображення жінки вводяться нові компоненти, специфічні ознаки жіночої прози не можуть бути фіксованими моделями, а видозмінюються від твору до твору. Усічені елементи, які письменниці використовують, додають експресивності і виразності описові подій.
\end{abstract}

Ключові слова: постмодернізм, валентність, інтент-аналіз, синкретизм, граматичний маркер. 


\section{Introduction}

Feminist literature is connected with important questions about the role of women in a family life, reconsideration of women's values and priorities, creation of a concept "woman as a centre of the society". A woman is not an addition to a man anymore. She is a personality with her own viewpoints, advantages and disadvantages of her nature. A woman enters the Universe, struggles for her place in the world community. The topic is implemented in the novels whose authors are women. A great interest in women's fiction makes scholars classify novels in accordance with the topics described in the literary works, as well as to distinguish between types and subtypes of women's novels. Nowadays, feminist literature has not achieved a proper acclaim yet. The novels have not been analyzed at all linguistic levels; sentences with repetition, syncretism, contracted elements at the text level have not been paid attention to. But to understand linguistic phenomena, we have to take into consideration the background on which lexical, semantic, pragmatic properties function - literature of the postmodern era and its distinctive features.

\section{The analysis of sources and recent researches}

Among scholars that started the theoretical background of Postmodern Literature, I. Hassan plays a special role (Hassan, 1982). D. Head continued the traditions of theoretical framework and studied the problems of Great Britain of 20th century and helped to understand the British literature of that period (Head, 2002). But he did not distinguish between the specific features of postmodernism. These features became a centre of linguistic interests for H. P. Wagner, though he did not offer the genre and thematic variety of the British postmodern novels (Wagner, 2010). Not long ago, characters in novels became brighter and more open, women turned up in the centre of the stories, the truth was taken from the details of life realities (Huddle, 1991). To denote love story or novel written by a woman, created for a woman and about a woman, new terms Romance, Frauenroman, Dameroman, Liebensroman appeared in the Western world (Lodge, 2000). Different forms that described the movement in the novels were dependant on aesthetic intention of a writer to direct the efforts through own system of rules (Bekhta, 2018: 15 - 30).

The aim of the paper is to describe the sentences with contracted predicates in the texts of British women's fiction.

\section{Statement of the basic material}

The feminist movement which caused the processes that helped women to play a significant role in the society became a pivot in creation of a new trend in literature - women's writing. From the beginning, novels have become full of suspense. Dialogues prevail over monologues. The inner world is described in details. Contracted or homogeneous parts of sentences help the authors to achieve the aim of narration in a better way. The contracted elements extend the structure of the sentence, enrich the vocabulary. They can function as a message, a desire, a command to characters and through characters to us. When using structures composed of two or more elements, the writer creates a special effect of influence on the readers. Events that take place in foreign lands, some hotels or summer houses are more stylistically marked. The reader waits what is next and wants to know if the marriage will survive in difficulties that the couple goes through.

Research algorithm of syntactic, semantic and communicative-pragmatic features of sentences with contracted elements involves the methods that add and correct each other at lexical and grammatical, semantic, and communicative-pragmatic levels that are interconnected.

Valency can be described as a semantically predictable connection of words. The predicate is a centre that attracts other words which add to the contents of a story. The analysis of valency of predicates shows that the predicate is the basic syntaxeme that forms the structure of the sentence:

She glanced at Hugh, then looked down at her glass. Her eyes looked strangely bright, as though some strong emotion had come to the fore, and Philip wondered what was wrong. A sudden surge of affection for Sam, or recognition that her son was nearly an adult. Perhaps she was still upset by their argument earlier. Or maybe it was just the drink. He reached for his own glass and took another swig, then reached for the wine. If he was going to get drunk he might as well get plastered (Wickham, 2010: 117).

Contracted elements are connected with the same subject; hence, they function as homogeneous parts, too. The sentences are extended by means of grammatical markers which show that the reader immediately waits for the next action. However, having the same subject, the contracted elements have different objects. In the second group of contracted elements, we come across the with three-component series of verbs. The conjunction and adverb as markers add expressiveness to the narration. Besides, the repetition of the same verb is a stylistic device that the author uses to emphasize the action, to prolong it, to add more weigh to each element. Every action is separate, with new meaning, though functions as one unit.

While using the transformational analysis, we can see the primary role of the predicative unit. Transformational analysis is based on the perception that every complicated syntactic structure consists of a simple one. Therefore, by means of consecutive transformations, simple structures originate from complex ones. The syntactic language system has several sub-systems from which one is primary and the rest are dependant. The simplest sentences that denote the simplest situations belong to the primary sub-type. Complex types of sentences are formed in the basic (primary) sentence through different transformations:

The boys were a welcome port in the storm that was Emily. They loved her and seemed to understand her, and she was sweet with them, and chatty, and revealed things in a way she never would with Andi, choosing instead to shut down whenever Andi was with them too (Green, 2012: 31).

Every sentence with contracted verbal or nominative predicates can be transformed and changed into a simple one, but to avoid the abundance of words, the writer uses contracted elements. The narration appears more colourful. The conjunction adds more and more information to the description. 
The component analysis reveals the components that function as parts of one unit. This coordination is expressed by means of grammatical markers; every marker has its own function within the sentence. The components coordinate as meaningful units and they create a special semantic type of a sentence. The elements are combined as structural units on the basis of arrangement of the whole sentence. The sentence structure is extended. In a linear location of components, next element responses or does not response to the requests of the previous one with the regard to the relations of Agent role and Accusative Case in clause structure where all parts are well organized (Poole, 2011: 334). In the same way, parts in sentences with contracted elements are strictly arranged:

I froze as he [Kyle] dragged his hands down his face and ran the palms of his hands across his eyes. Then, slowly, like he was moving with a heavy heart, like he didn't want to do what he was about to do, he stood and turned to the door. He stopped when he saw me. Stopped, stared. His face was a mass of blotches, his eyes shot through with red, the tip of his running nose also a pinker shade of scarlet (Koomson, 2007: 411).

Contracted elements are used in a logical order. The change of an order can shift the semantics of each component. Conjunctions pair the actions that follow each other. Punctuation mark slows down the tempo of the story. Moreover, syncretic models separate actions from each other; the author intentionally pauses the narration. The character stopped, stared. The list of verbs can be continued. Syncretism is implementation of language economy on different levels. The principle of language economy plays a significant role in a text. The author wants to express some ideas in the text, she has the right to omit a word, a phrase. The text is minimized. By means of less words, more ideas are presented to the reader.

Intent analysis can help to identify intention which motivates the usage of contracted elements and is expressed at the language level:

Sadie looks appalled. 'How are you going to forget him [Josh] if you keep talking about him? Darling, when things go wrong in life, this is what you do.' She adopts a knowledgeable tone. 'You lift your chin, put on a ravishing smile, mix yourself a little cocktail ... and out you go.' (Kinsella, 2010: 107).

Every contracted element in a series requires a logical order. The order of actions can be changed but it won't make sense. The character advises to take steps to relax, to cheer up. The verbs are used with the specific intention.

Communicative intention is the central component of communicative-pragmatic structure. It is a communicative-pragmatic index that directs an action. It functions as a speech action of different types; its role is to implement expressiveness, directness (Carston, 2002).

Both structural and semantic features should be taken into consideration while studying the sentence. Lexical "container" of the predicate takes part in semantic construction of the sentence. Lexemes of specific semantic types can be selected for the syntactic positions in the sentence. Lexical semantics of sentence components is coordinated with the semantics of the structural scheme:

She [Annie] had been polite, attentive and coolly well-mannered, but the look in her eye had suggested more violent feelings. Those Annie did fathom. She had served a Sunday lunch of roast beef with trimmings in a dining room furnished as if it was a miniature stately home, which was a little ridiculous for a tiny cottage ... Did Tom's mother knit? Or cook using recipe books? Appreciate flowers? To Annie, she appeared a woman without form or vanity or hinterland (Buchan, 2010: 246).

The first part of the contracted elements is expressed by means of adjectives, though verbs are used in the second group. The intention is clear. We come across comparison that differentiate the features of behavior of Annie from actions of Tom's mother. Annie served the interests of the family. The middle part of the text shows what activities she is involved in. That is what her husband wants from her. But she cannot be a slave in her own house. Did Tom have all these from his mother? Annie does not want to stand her status. She protests as any woman does in the era of postmodernism.

\section{Conclusions}

Contracted predicates extend the sentences, cause additional element in an object perception. Writers use contracted elements to describe emotional state of the characters in their novels. Grammatical markers make a story tempo either fast or slow. By means of contracted elements, we identify the pragmatic subtype: a message, a promise, a gratitude, a request, a command, a desire. A complex approach enables to study the object of our research completely. Lexical and grammatical level of research enables to define the sentences with contracted elements as syntactic units that are made up of principal and subordinate parts of sentences that are connected with each other. Semantic level adds to an understanding of parts of sentences; a meaning (direct or figurative) takes part in construction of a speech unit. On the basis of analysis of the communicative and pragmatic level, sentences with contracted elements are implemented into the speech acts which are analyzed as communicative-pragmatic units of speech activity that is directed at the implementation of intention in the communicative situation described in novels.

Repetition of syntactic structures, syncretic models, a series of two- or polycomponent elements help to enter the world of characters, co-experience their life.

Further research will be based on a thorough observation of typology of the constructions with contracted elements, their functional and pragmatic characteristics.

\section{References:}

1. Baerman, M., Brown, D., Corbett, G.G. (2005). The Syntax-Morphology Interface. New York : Cambridge University Press.

2. Bekhta, N. (2018). Reading experimental literature: unreadability, discomfort and reading strategies. Reading today. (Ed. Heta Pyrhönen, Janna Kantola) (pp. 15 - 30). London : University College London Press. 
3. Buchan, E. (2010). Separate Beds. Penguin Books.

4. Carston, R. (2002). Thoughts and Utterances: The Pragmatics of Explicit Communication. Oxford: Blackwell.

5. Green, J. (2012). The Patchwork Marriage. Penguin Books.

6. Hassan, I. (1982). The Dismemberment of Orpheus: Toward a Postmodern Literature. Medison : The University of Wisconsin Press.

7. Head, D. (2002). The Cambridge Introduction to Modern British Fiction, 1950-2000. Cambridge : University Press.

8. Huddle, D. (1991). The writing habit. University Press of New England.

9. Kinsella, S. (2010). Twenties Girl. Black Swan.

10. Koomson, D. (2007). Marshmallows for Breakfast. Sphere.

11. Lodge, D., Wood, N. (Eds.). (2000). Encyclopedia of Modern Criticism and Theory. London : Longman.

12. Poole, G. (2011). Syntactic Theory. Palgrave Macmilan.

13. Wagner, H.P. (2010). A History of British, Irish and American Literature. Trier.

14. Wickham, M. (2010). Sleeping Arrangements. Black Swan. 